\title{
QUEEN'S
UNIVERSITY
BELFAST
}

\section{A Validation Study of Vascular Cognitive Impairment Genetics Meta- Analysis Findings in an Independent Collaborative Cohort}

Skrobot, O. A., McKnight, A. J., Passmore, P. A., Seripa, D., Mecocci, P., Panza, F., Kalaria, R., Wilcock, G., Munafò, M., Erkinjuntti, T., Karhunen, P., Pessi, T., Martiskainen, M., Love, S., Kehoe, P. G., \& Genetic and Environmental Risk for Alzheimer's disease Consortium (GERAD1) (2016). A Validation Study of Vascular Cognitive Impairment Genetics Meta-Analysis Findings in an Independent Collaborative Cohort. Journal of Alzheimer's disease : JAD. https://doi.org/10.3233/JAD-150862

Published in:

Journal of Alzheimer's disease : JAD

Document Version:

Peer reviewed version

Queen's University Belfast - Research Portal:

Link to publication record in Queen's University Belfast Research Portal

Publisher rights

Copyright 2016 The Authors

The final publication is available at IOS Press through http://dx.doi.org/10.3233/JAD-150862

General rights

Copyright for the publications made accessible via the Queen's University Belfast Research Portal is retained by the author(s) and / or other copyright owners and it is a condition of accessing these publications that users recognise and abide by the legal requirements associated with these rights.

Take down policy

The Research Portal is Queen's institutional repository that provides access to Queen's research output. Every effort has been made to ensure that content in the Research Portal does not infringe any person's rights, or applicable UK laws. If you discover content in the Research Portal that you believe breaches copyright or violates any law, please contact openaccess@qub.ac.uk. 
A validation study of Vascular Cognitive Impairment genetics meta-analysis findings in an independent collaborative cohort

Olivia Anna Skrobot ${ }^{\mathrm{a}}$, Amy Jayne McKnight ${ }^{\mathrm{b}}$, Peter Anthony Passmore ${ }^{\mathrm{c}}$, Davide Seripa ${ }^{\mathrm{d}}$, Patrizia Mecoccie, Francesco Panza d,f , Rajesh Kalariag, Gordon Wilcock ${ }^{\text {h }}$, Marcus Munafòi, Timo Erkinjunttij, Pekka Karhunen ${ }^{k, l}$, Tanja Pessi $^{k, l}$, Mika Martiskainen $^{k, l}$, Seth Love ${ }^{a}$, the Genetic and Environmental Risk for Alzheimer's disease Consortium (GERAD1)\#, Patrick Gavin Kehoe ${ }^{a *}$

aDementia Research Group, University of Bristol, Level 1, Learning \& Research, Southmead Hospital, Bristol, BS10 5NB UK; ${ }^{b}$ Centre for Public Health, Queen's University of Belfast, c/o Regional Genetics Centre, Level A, Tower Block, Belfast City Hospital, BT9 7AB; ' Institute of Clinical Sciences, Block B, Queens University Belfast, Royal Victoria Hospital, Belfast, BT12 6BA; 'Geriatric Unit \& GerontologyGeriatrics Research Laboratory, Department of Medical Sciences, I.R.C.C.S. "Casa Sollievo della Sofferenza", Viale Cappuccini 1, 71013 San Giovanni Rotondo (FG), Italy; ${ }^{\mathrm{e}}$ Institute of Gerontology and Geriatrics, University of Perugia, Ospedale S.M. della Misericordia, 06156 Perugia, Italy; ${ }^{f}$ Neurodegenerative Disease Unit, Department of Basic Medicine, Neuroscience, and Sense Organs, University of Bari Aldo Moro, Policlinico, Piazza Giulio Cesare 11, 70124 Bari, Italy; Institute of Neuroscience, NIHR Biomedical Research Building, Campus for Ageing \& Vitality Newcastle upon Tyne, NE4 5PL, United Kingdom; ${ }^{\mathrm{h}}$ Nuffield Department of Clinical Neurosciences, University of Oxford, Level 6, West Wing, John Radcliffe Hospital, Headington, Oxford, UK OX3 9DU; 'MRC Integrative Epidemiology Unit, UK Centre for Tobacco and Alcohol Studies, School of Experimental Psychology, University of Bristol, 12a Priory Road, Bristol BS8 1TU, UK; 'Department of Neurology and Memory Research Unit, Helsinki University Central Hospital, POB 300, FIN-00029 HUS, Finland; ${ }^{k}$ School of Medicine, University of Tampere, Finland; 'Fimlab Laboratories Ltd, Tampere University Hospital region, Finland; " Data used in the preparation of this article were obtained from the Genetic and Environmental Risk for Alzheimer's disease (GERAD1) consortium. As such, the 
investigators within the GERAD1 consortia contributed to the design and implementation of GERAD1 and/or provided data but did not participate in analysis or writing of this report.

* Corresponding author:Patrick.Kehoe@bristol.ac.uk, Tel: +44 (0)117 4147821, Fax: +44 (0) 117 4147822

Keywords: Association, gene, dementia, vascular, meta-analysis, cognitive impairment 


\section{Abstract}

Vascular cognitive impairment ( $\mathrm{VCl})$, including its severe form vascular dementia (VaD), is the second most common form of dementia. The genetic aetiology of sporadic $\mathrm{VCl}$ remains largely unknown. We previously conducted a systematic review and meta-analysis (MA) of all published genetic association studies of sporadic VCl prior to 6 July 2012, which demonstrated that $A P O E(\varepsilon 4, \varepsilon 2)$ and MTHFR (rs1801133) variants were associated with susceptibility for $\mathrm{VCl}$. De novo genotyping was conducted in a new independent relatively large collaborative European cohort of $\operatorname{VaD}\left(n_{\max }=549\right)$ and elderly non-demented samples $\left(n_{\max }=552\right)$. Where available, genotype data derived from Illumina's 610-quad array for 1210 GERAD1 control samples were also included in analyses of genes examined. Associations were tested using the Cochran-Armitage trend test: MTHFR rs1801133 (OR= $1.36,95 \% \mathrm{Cl} 1.16-1.58, \mathrm{p}=<0.0001), A P O E \mathrm{rs} 7412(\mathrm{OR}=0.62,95 \% \mathrm{Cl} 0.42-0.90, \mathrm{p}=0.01)$, and $A P O E$ rs429358 (OR=1.59, 95\% $\mathrm{Cl} 1.17-2.16, \mathrm{p}=0.003)$. Association was also observed with APOE epsilon alleles; $\varepsilon 4(\mathrm{OR}=1.85,95 \% \mathrm{Cl} 1.35-2.52, \mathrm{p}=<0.0001)$; and $A P O E \varepsilon 2,(\mathrm{OR}=0.67,95 \% \mathrm{Cl} 0.46-0.98, \mathrm{p}=$ 0.03). Logistic Regression and Bonferroni correction in a subgroup of the cohort adjusted for gender, age and population maintained the association of $A P O E$ rs429358 and $\varepsilon 4$ allele.

\section{Introduction}

Vascular Cognitive Impairment ( $\mathrm{VCl}$ ) represents a heterogeneous group of related conditions involving cognitive decline resulting from cerebrovascular disease or systemic disease that leads to inadequate cerebrovascular supply. Vascular dementia (VaD), an older and more commonly used term to describe more severe forms of $\mathrm{VCl}$, is widely accepted to represent less than a fifth of all dementias and is arguably the second most common form of dementia after Alzheimer's disease (AD). However, there is ongoing debate regarding the validity and utility of distinguishing between $A D$ and $\operatorname{VaD}$ given the very high presence of cerebrovascular disease in $A D[1,2]$. Indeed, it has been proposed that $\mathrm{VCl}$ will become the foremost cause of dementia given the ageing demographics and escalating rates of stroke and ischaemic heart disease $[3,4]$. 
Risk factors for common non-autosomal dominant inherited forms of $\mathrm{VCl}$ (i.e. sporadic $\mathrm{VCl}$ ) strongly overlap with risk factors for those associated with AD. These include hypertension, diabetes mellitus, smoking, atrial fibrillation, positive family history, age and hypercholesterolaemia[5, 6]. However, as yet, little is still known about the extent to which genetic variation contributes to risk of $\mathrm{VCl}$, which as is the case in $A D$, is likely to interact with various environmental influences.

Despite the extensive overlap between risk factors for $A D$, stroke and $\mathrm{VCl}$, there has not been as much research into the molecular and genetic basis of $\mathrm{VCl}$. This contrasts markedly with the volume of similar activity that has occurred, and proven beneficial in terms of AD research for over two decades[7]. The slower emergence of studies in $\mathrm{VaD}$ and $\mathrm{VCl}$ is most likely due to the lower prevalence and highly heterogeneous nature of $\mathrm{VCl}$, both of which are factors that have also served to frustrate development of universally accepted means of $\mathrm{VCl}$ classification. This is highlighted by the numerous diagnostic and other research-based criteria and guidelines for $\mathrm{VCl}$ that have been developed to provide constructs for the classification of forms of $\mathrm{VCl}$ to facilitate research $[4,8-10]$ but in reality have been used to varying extents. Thus large-scale collaborative endeavours that are ordinarily needed to properly study diseases of lower prevalence such as VCI have not yet been regularly realised. Furthermore there are issues on the level of interpretation and inference that can be made across different smaller-scale studies. As a consequence of these factors, thus far, susceptibility genes of $\mathrm{VCl}$, particularly those of small effect most likely remain undiscovered.

A useful, rapid and relatively low cost tool to explore and maximise the amount of information that can be extracted from what may be considered to be a number of inadequately powered individual studies of $\mathrm{VCl}$ is meta-analysis (MA). Recently we used MA to investigate a limited number of selected (i.e. most commonly studied) candidate genes, partly suggested by previously reported associations with $A D$, and having cardiovascular properties also relevant to $\mathrm{VaD}$ including; 
Apoliopoprotein (APOE), methylenetetrahydrofolate reductase (MTHFR) and angiotensin converting enzyme (ACE) polymorphisms [11-14]. In our previous study [15], we used a combined systematic review and MA approach of all published candidate gene studies of sporadic VCI to identify potentially important candidate genes for $\mathrm{VCl}$. This allowed us to try and address some of the shortcomings of previous studies in terms of statistical power, whilst acknowledging the heterogeneous nature of $\mathrm{VCl}$. Associations with increased risk for $\mathrm{VCl}$ were found for $A P O E \& 4$ (OR= $1.818,95 \% \mathrm{Cl} 1.611$ to $2.053, \mathrm{p}=<0.001 ; \mathrm{N}=3,554$ cases, $\mathrm{N}=12,277$ controls) and MTHFR rs 1801133 ( $\mathrm{OR}=1.323,95 \% \mathrm{Cl} 1.061$ to $1.650, \mathrm{p}=0.013 ; \mathrm{N}=659$ cases, $\mathrm{N}=981$ controls). There was weak evidence of a protective effect for $A P O E \& 2$ (OR= $0.885,95 \% \mathrm{Cl} 0.783$ to $0.999, \mathrm{p}=0.048 ; \mathrm{N}=3,320$ cases, $\mathrm{N}=10,786$ controls). $\mathrm{MA}$ of polymorphisms: rs4934 of Alpha-1-antichymotrypsin ( $A C T$, now formally referred to as SERPINA3); rs1799752 (intron 16 indel variant) of ACE; rs662 of Paraoxonase 1 (PON-1); and the rs165932 variant of presenilin-1 (PSEN-1) showed no evidence for association [15].

In general, MA of multiple small studies may also suffer from between-study heterogeneity, or be of inferior methodological quality [16], including the use of different clinical diagnostic criteria. Many of these factors can give rise to disproportionally larger or small effect sizes for any gene found to be of interest. Considering these limitations, we attempted to validate our MA findings by genotyping the polymorphisms previously found to be interesting [15], in a uniformly diagnosed unprecedented cohort of archival DNA from VaD patients and healthy controls of European decent, thereby minimising variation in methodology and interpretation.

\section{Materials and Methods}

The collaborative cohort consists of archival samples from the United Kingdom (UK) $(n=278)$ and Italy ( $n=823$ ). Age and gender was available for a subsection of the cohort: mean age VaD $78.74 \pm$ $0.32(n=509), 232$ males/296 females; mean age controls $76.83 \pm 0.43,(n=513), 233$ males/316 
females. VaD cases were clinically diagnosed according to NINDS-AIREN criterion [8]. A sample of $549 \mathrm{VaD}$ cases and 552 controls were genotyped using Sequenom iPLEX Gold (97.7\% success rate) for a number of polymorphisms (see Table 1). Polymorphism rs4343 in ACE was genotyped as a proxy for the ACE I/D [17]. SERPINA3 (ACT) rs4934 was genotyped using Taqman (TaqMan C_2188895_10) and analysed using Sequence Detection Software version 2.4. All SNPs were concordant for HWE at P>0.001. SNPs rs429358 and rs7412 were directly genotyped and APOE epsilon alleles calculated - in brief the T allele at both APOE SNPs identified the $\varepsilon 2$ allele, whereas the $C$ allele at both positions constitutes the $\varepsilon 4$ allele. The T allele at rs 429358 and the $C$ allele at rs7412 identify the $\varepsilon 3$ allele, which is the most common allele in the general population[18]. Genotype data from an additional 1210 non-demented elderly individuals (451 males/759 females), from UK $(n=830)$, Northern Ireland $(n=110)$, Germany $(n=37)$ and United States $(n=233)$ that were collected as part of the GERAD1 consortium [19] that were used in AD Genome Wide Association Studies (GWAS) genotyped on the Illumina 610-quad chip (as described [19]), was available for inclusion in the analysis for MTHFR rs1801133 and PON-1 rs662. Age was available for 1133 individuals; mean $76.34 \pm 0.20$. Genetic association of susceptibility to $\mathrm{VaD}$ were independently evaluated using the test for trend implemented in PLINK [20], with logistic regression (LR) analysis for age, gender, and population. A p-value $<0.05$ was considered nominal evidence for statistical significance and supportive of our previous findings [15]. SNP-SNP interactions were also analysed in 426 cases and 1730 controls using PLINK ALL x ALL epistasis mode with the odds ratio calculated for interaction and $p$ values adjusted for the multiple tests performed.

\section{Results}

Associations were identified using the Cochran-Armitage trend test for MTHFR rs1801133 (OR=1.36, $95 \% \mathrm{Cl} 1.16$ to $1.58, \mathrm{p}=0.000095), A P O E$ rs7412 (OR= $0.62,95 \% \mathrm{Cl} 0.42$ to $0.90, \mathrm{p}=0.01)$, and $A P O E$ rs429358 (OR=1.59, 95\% $\mathrm{Cl} 1.17$ to $2.16, \mathrm{p}=0.003)$ (Table 1$)$. Association was also observed with 
APOE epsilon alleles $(\varepsilon 4: \mathrm{OR}=1.85,95 \% \mathrm{Cl} 1.35$ to $2.52, \mathrm{p}=0.00005 ; \varepsilon 2: \mathrm{OR}=0.67,95 \% \mathrm{Cl} 0.46$ to 0.98, $p=0.03$ ); allelic distributions are provided in Table 2 .

APOE and MTHFR associations were robust to Bonferroni correction, although logistic regression analysis in a subgroup of the cohort adjusted for gender, age and population reduced the strength of all associations (Table 1). However, associations for APOE rs429358 (OR=1.66, 95\% $\mathrm{Cl} 1.19$ to 2.32, $\mathrm{p}=0.003)$ and $\varepsilon 4$ allele $(\mathrm{OR}=1.61,95 \% \mathrm{Cl} 1.52$ to $1.72, \mathrm{p}=0.0001)$ were robust to these adjustments.

There was no evidence of association between $\mathrm{VCl}$ risk and variants in a number of other genes that were included in our previous MA study and which here also showed lack of association: rs4934 of ACT; rs1799752 of ACE; rs662 of PON-1; and rs165932 of PSEN-1 (Table 1).

Epistasis, defined typically as the interaction between different genes, has revealed many novel biological insights for complex disease genetics in recent years. The presence of an allele at one SNP loci may interact with alleles at other loci to exert a complementary or specific effect on gene expression and / or function. For example, genes involved may be part of multi-component proteins, the same biological pathway, or disease mechanism and exert modifier effects on phenotypes. As the genes investigated in this study have been suggested to contribute to $\mathrm{VCl}$, we evaluated if SNPs demonstrated independent effects. Using the integrated epistasis approach implemented in PLINK (All x ALL command) we tested pairwise combinations of all SNPs across all genes for 426 case and 1730 control individuals; no SNP-SNP interaction was statistically significant following Bonferroni correction for multiple testing (data not shown).

\section{Discussion}

This study provides supportive evidence, in an independent European cohort of VaD patients and non-demented elderly, of association between variants in APOE and MTHFR and susceptibility for 
VaD, that validate previous findings for these genes demonstrated by MA [15]. In agreement, we found no association for PON-1 rs662, SERPINA3 (ACT) rs4934; PSEN-1 rs165932 or ACE rs1799752 as investigated in our previous MA [15]. This supports the utility of MA as a method to maximise the amount of information that can be extracted from a series of published unrelated and small casecontrol association studies, which individually only allow for limited interpretation because of low statistical power. In a subsequently published MA, the same findings for these SNPs were reported, albeit with the inclusion of varying studies[14].

\section{APOE}

Apoliopoprotein (APOE) plays a key role in lipid metabolism of cholesterol and triglycerides used to support synaptogenesis and the maintenance of synaptic connections [21]. APOE has also been associated with increased risk of cerebral amyloid angiopathy $[22,23]$ as well as cardiovascular and cerebrovascular atherosclerosis, coronary heart disease, and high total serum cholesterol. Collectively the role of APOE in a number of vascular conditions, each of which could contribute to $\mathrm{VCl}$, clearly makes $A P O E$ a strong candidate gene for $\mathrm{VCl}$ risk. There have also been numerous studies exploring possible association of $A P O E \varepsilon 4$ with ischaemic stroke, as recently reviewed by Stankovic and Majkic-Singh, however, results on this thus far are conflicting [24].

Our published MA of 63 cohorts totalling 3,554 cases and 12,277 controls showed that APOE $\varepsilon 4$ was associated with increased risk of $\mathrm{VCI}[15]$. Separate MA of people who were classified against specific definitions of $\operatorname{VaD}(\mathrm{OR}=1.913,95 \% \mathrm{Cl} 1.683$ to $2.173, \mathrm{p}=<0.001 ; \mathrm{N}=2,422$ cases, $\mathrm{N}=9,722$ controls $)$ also showed evidence of association. Stratification of $A P O E \varepsilon 4$ data by ethnicity also showed evidence of association with Asian, and European groups (OR=1.939, 95\% $\mathrm{Cl} 1.576$ to $2.386, \mathrm{p}=$ $<0.001 ; \mathrm{N}=1,268$ cases, $\mathrm{N}=4,078$ controls). The association we previously identified by MA with susceptibility for VaD in Europeans was further supported in this study that comprised a large 
European cohort; of particular note, the odds ratio in this study $(O R=1.85)$ is strikingly similar to that previously reported $(\mathrm{OR}=1.82)$ for $\mathrm{VCl}$.

Our previously published MA of $A P O E \varepsilon 2$ revealed a protective effect against $\mathrm{VaD}$ and in the analysis of all cohorts under a broader $\mathrm{VCl}$ term. The protective effect of $A P O E \varepsilon 2$ against $\mathrm{VaD}(\mathrm{OR}=0.812$ $95 \% \mathrm{Cl} 0.698$ to $0.945, \mathrm{p}=0.007 ; \mathrm{N}=2,247$ cases, $\mathrm{N}=8,967$ controls) was further supported in the current case-control study although statistical evidence was only weak ( $\mathrm{OR}=0.67,95 \% \mathrm{Cl} 0.46$ to $0.98, \mathrm{p}=0.03) . A P O E \varepsilon 2$ may have a protective effect in coronary artery disease, a disease mediated by altered lipoprotein levels, inflammatory and immune activities [25].

\section{MTHFR rs1801133}

Methylenetetrahydrofolate reductase (MTHFR) is a key rate-limiting enzyme in the metabolism of homocysteine (Hcy). The rs1801133 (also known as C677T) polymorphism of MTHFR has been associated with reduced enzyme activity and increase serum Hcy levels [26]. It has also been linked to several vascular diseases including risk of coronary heart disease and hypertension [27], as well as with cognitive impairment [28]. One of the largest MA of 32 published articles (6110 cases/8760 controls) that investigated this polymorphism in relation to risk of ischaemic stroke/TIA, found that the T allele was associated with increased risk of stroke in a graded, dose-dependent manner ( $T$ allele pooled $\mathrm{OR}=1.17 ; 95 \% \mathrm{Cl} 0.09-1.26$; TT genotype pooled $\mathrm{OR}=1.37 ; 95 \% \mathrm{Cl} 1.15-1.64)$ [29].

There have been conflicting findings regarding the association between this MTHFR polymorphism with stroke, however seven out of $11 \mathrm{MA}$ of stroke that have been previously undertaken have shown an association for C677T [24]. The discrepancies may relate to the fact that the C677T polymorphism varies in different ethnic populations, ranging from less than $1 \%$ to $21 \%$ [30]. Furthermore, an association of MTHFR rs1801133 with AD was only found when the co-occurrence of $A P O E \varepsilon 4$ was also included in the analysis [31] suggesting an epistatic interaction. Indeed a similar 
observation was also found for IL-6 rs 1800795 in both AD and VaD [32]. Of particular interest is that analysis of the MTHFR rs1801133 by HaploReg version 2 [33] reveals multiple epigenetic effects for this SNP in a European population. Characterising the downstream effects of genetic mutations associated with disease is challenging. One approach is to evaluate associations between diseaseassociated SNPs and the expression levels of local genes (cis effects) and downstream consequences that are more distant from the target SNP (trans effects). Westra and colleagues [34] performed a systematic evaluation of expression quantitative trait loci (eQTLs) using next generation sequencing in >8,000 individuals; their results were published in Nature Genetics and made publicly available, thus providing a rich resource for researchers. We interrogated this valuable dataset for putative functionality of top-ranked SNPs in this study and presented relevant results in Table 3 to support biological insights for MTHFR. Rs1801133 has an impact on both epigenetics and the expression of several genes, with this association exceeding traditional genome-wide significance values (Table 3). The cis-eQTI links for blood are strongest for Mitofusin 2 gene (MFN2) central to mitochondrial fusion and important in the regulation of vascular smooth muscle cell proliferation[35], with defects associated with disorders of PNS [36], early events in ischaemic stroke and neurodegeneration [3739].

The results of our MA for MTHFR rs1801133 in VCl also showed an association of the T allele and increased risk of $\mathrm{VCl}$ and in the smaller $\mathrm{MA}$ of $\mathrm{VaD}$ cases we also found association $(\mathrm{OR}=1.309,95 \%$ Cl 1.121 to $1.528, p=0.001 ; \mathrm{N}=616$ cases, $\mathrm{N}=981$ controls). However, the majority of studies that were included in this MA were Asian and only 2 studies were Caucasian, with stratified analysis showing that Asian but not Caucasian cohorts ( $\mathrm{OR}=1.644,95 \% \mathrm{Cl} 0.597$ to 4.528$), \mathrm{p}=0.336 ; \mathrm{N}=136$ cases, $\mathrm{N}=125$ controls) were associated. The current European case-control study, which is larger than the combined sample size in the original MA, supported the presence of association with $\mathrm{VaD}$ and now provides evidence of association in Caucasians ( $\mathrm{OR}=1.36,95 \% \mathrm{Cl} 1.16$ to $1.58, \mathrm{p}=0.0001$ ). The odds ratio in this study $(\mathrm{OR}=1.36)$ is similar to the $\mathrm{VCl}$ association $(\mathrm{OR}=1.32)$ previously 
reported, suggesting a similar effect size for both phenotypes, however it should be noted that the LR model accounting for age, gender and population in a subsection of the cohort did not show evidence of association in the current collection.

In this study of European subjects, there was no evidence of an epistatic interaction between $A P O E$ and MTHFR polymorphisms, supporting the hypothesis that MTHFR might serve as an independent genetic risk factor for $\mathrm{VCl}$. In future studies of $\mathrm{VCl}$, it is worth considering the testing of epistasis in a routine manner, where statistical power may allow, to avoid missing clues to risk variants that might otherwise be overlooked.

While there was no evidence of association for SERPINA3 (ACT) rs4934 and PSEN-1 rs165932, the lack of association with either may relate to the fact most of the biological evidence of the potential involvement of both resultant proteins is more related to their roles in aspects of $A D$ and in particular that of $A \beta$ peptide pathology [40] that is not part of the main neuropathology of VaD. Yet, the function of SERPINA3 might have been more plausible as an acute phase protein that is released in response to inflammatory stimuli that have been suggested in early stages of dementia [41].

The PON-1 rs662 and ACE rs1799752 were arguably stronger candidate genes for $\mathrm{VCl}$ since Paraoxonase 1 (PON-1) has a vascular function as a component of high-density lipoprotein (HDL) but is also important for Hcy metabolism while angiotensin converting enzyme (ACE) plays an important part in the regulation of systemic blood pressure and fluid electrolyte balance with hypertension one of the biggest risk factors for $\mathrm{VCl}$ [42]. With respect to PON-1, despite links to Hcy metabolism, association with ischemic stroke [43] and synergistic interactions between genes of related processes shown in coronary artery disease patients [44], in this study we found no evidence of epistatic interactions. In contrast, the $\mathrm{D}$ allele of $A C E$ has been suggested, albeit with many conflicting studies, to be associated with risk factors for $\mathrm{VCl}$ including; myocardial infarction, stroke, 
cardiovascular disease, essential hypertension, diabetes mellitus and leukoaraiosis in patients with ischemic stroke [45]. Yet we found no evidence here, nor in the previous MA study to support any association, in agreement with another recent study on $\operatorname{VaD}[11]$.

\section{Study Limitations}

Associations for APOE and MTHFR were robust to Bonferroni correction, although logistic regression analysis in a subgroup of the cohort adjusted for gender, age and population reduced the strength of all associations (Table 1). However, only a reduced number of cases could be included in this more detailed level of analysis, due to the lack of covariate data available for a substantial proportion of these archival samples, thus reducing the power to identify such associations. Furthermore, the identification of candidate genes by MA is limited and wholly determined by what studies have been previously conducted and are suitable for inclusion in the analysis. MA has limitations and biases in the same way as any hypothesis-driven approaches towards the discovery of risk genes. More recently the use of GWAS has been developed to address this, whilst itself still being limited by the amount of gene variants that are included.

\section{Emerging evidence of the genetic aetiology from Genome Wide Associations Studies (GWAS)}

Rs12007229, a single nucleotide variant of no known function located on the $\mathrm{X}$ chromosome, which is near the androgen receptor gene $(\mathrm{OR}=3.7,95 \% \mathrm{Cl} 2.3-5.8$, per copy of the minor allele; $P=$ $\left.1.3 \times 10^{-8}\right)[46]$ was identified in 2012 in the first GWAS of VaD. Although a first for this disease it was somewhat limited as it involved data from a total of just over 300 incident and prevalent cases of VaD that were compared to a Dutch population-based discovery cohort of 5700 subjects. Another GWAS reported a novel association with an intronic variant of rs290227 within the spleen tyrosine kinase (SYK) gene [47] from a cohort of 87 Korean VaD patients and 200 controls. A comparison of these two GWAS could not identify common nucleotide variants[48], yet the potential power of GWAS to identify new variants, in relatively small cohorts is highlighted. However, in neither of these 
GWAS (which are both considerably smaller in sample size to either the original MA or this replication study) was there any evidence found to support the involvement of APOE or MTHFR as a risk factor.

\section{Conclusions}

We report that variations in both $A P O E$ and MTHFR are associated with increased risk of VaD. While the potential involvement of MTHFR in VCl risk is interesting, it still needs further independent replication. However, the robust association seen here, and in previous MA for the $A P O E \varepsilon 4$ variant as a risk factor strongly support the validity of using $A P O E$ variants as a necessary co-variant in analysis of other genetic susceptibility factors of $\mathrm{VCl}$, similar to how it has been widely applied in genetic studies of AD. GWAS is likely to serve as the most likely method by which to pursue the identification of new candidate genes for $\mathrm{VCl}$ in the future. However, future successes are also likely to be dependent upon the availability of large numbers of samples that will only come via collaboration such as has been seen to generate considerable success in recent years in the AD field where approximately 32 genes have now been identified [49].

\section{Acknowledgements}

This work and OAS are supported by a project grant (Ref117) from the Alzheimer's Society (UK). PGK is supported by the Sigmund Gestetner Foundation. We would like to thank the South West Dementia Brain Bank (SWDBB) for providing brain tissue for this study. The SWDBB is supported by BRACE (Bristol Research into Alzheimer's and Care of the Elderly), Brains for Dementia Research and the Medical Research Council.

This study incorporated control data from the Genetic and Environmental Risk for Alzheimer's disease Consortium (GERAD1) genome-wide association study [18]. GERAD1 Acknowledgements: Cardiff University was supported by the Wellcome Trust, MRC, Alzheimer's Research UK (ARUK) and the Welsh Assembly Government. ARUK supported sample collections at the Kings College London, 
the South West Dementia Bank, Universities of Cambridge, Nottingham, Manchester and Belfast. The Belfast group acknowledges support from the Alzheimer's Society, Ulster Garden Villages, N. Ireland R\&D Office and the Royal College of Physicians/Dunhill Medical Trust. The MRC and Mercer's Institute for Research on Ageing supported the Trinity College group. The South West Dementia Brain Bank acknowledges support from Bristol Research into Alzheimer's care of the Elderly. The Charles Wolfson Charitable Trust supported the OPTIMA group. Washington University was funded by NIH grants, Barnes Jewish Foundation and the Charles and Joanne Knight Alzheimer's Research Initiative. Patient recruitment for the MRC Prion Unit/UCL Department of Neurodegenerative Disease collection was supported by the UCLH/UCL Biomedical Centre, Laser-AD was funded by Lundbeck SA. The Bonn group was supported by the German Federal Ministry of Education and Research (BMBF), Competence Network Dementia and Competence Network Degenerative Dementia, and by the Alfried Krupp von Bohlen und Halbach-Stiftung.

The Newcastle Brain Tissue Resource is funded by a grant from the UK MRC (G0400074) with further support from the Newcastle NIHR Biomedical Research Centre in Ageing and Age Related Diseases award to the Newcastle upon Tyne Hospitals NHS Foundation Trust, and a grant from the Alzheimer's Society and ARUK as part of the Brains for Dementia Research Project.

P.G.K would like to acknowledge the support of the Sigmund Gestetner Foundation.

G.W was partly funded by the NIHR Biomedical Research Centre Programme, Oxford.

T.P wishes to acknowledge Jane and Aatos Erkko Foundation.

\section{References}

[1] Attems J, Jellinger KA (2014) The overlap between vascular disease and Alzheimer's disease-lessons from pathology. BMC Med 12, 206.

[2] O'Brien JT, Markus HS (2014) Vascular risk factors and Alzheimer's disease. BMC Med 12, 218.

[3] Roman GC (2002) Vascular dementia may be the most common form of dementia in the elderly. Journal of the Neurological Sciences 203, 7-10. 
[4] Gorelick PB, Scuteri A, Black SE, Decarli C, Greenberg SM, ladecola C, Launer LJ, Laurent S, Lopez OL, Nyenhuis D, Petersen RC, Schneider JA, Tzourio C, Arnett DK, Bennett DA, Chui HC, Higashida RT, Lindquist R, Nilsson PM, Roman GC, Sellke FW, Seshadri S, American Heart Association Stroke Council CoE, Prevention CoCNCoCR, Intervention, Council on Cardiovascular S, Anesthesia (2011) Vascular contributions to cognitive impairment and dementia: a statement for healthcare professionals from the american heart association/american stroke association. Stroke 42, 2672-2713.

[5] Kester MI, Scheltens P (2009) Dementia: the bare essentials. Pract Neurol 9, 241-251.

[6] Akinyemi RO, Mukaetova-Ladinska EB, Attems J, Ihara M, Kalaria RN (2013) Vascular risk factors and neurodegeneration in ageing related dementias: Alzheimer's disease and vascular dementia. Curr Alzheimer Res 10, 642-653.

[7] Bertram L, McQueen MB, Mullin K, Blacker D, Tanzi RE (2007) Systematic meta-analyses of Alzheimer disease genetic association studies: the AlzGene database. Nature Genetics 39, 17-23.

[8] Roman GC, Tatemichi TK, Erkinjuntti T, Cummings JL, Masdeu JC, Garcia JH, Amaducci L, Orgogozo JM, Brun A, Hofman A, Moody DM, Obrien MD, Yamaguchi T, Grafman J, Drayer $B P$, Bennett DA, Fisher M, Ogata J, Kokmen E, Bermejo F, Wolf PA, Gorelick PB, Bick KL, Pajeau AK, Bell MA, Decarli C, Culebras A, Korczyn AD, Bogousslavsky J, Hartmann A, Scheinberg P (1993) VASCULAR DEMENTIA - DIAGNOSTIC-CRITERIA FOR RESEARCH STUDIES REPORT OF THE NINDS-AIREN INTERNATIONAL WORKSHOP. Neurology 43, 250-260.

[9] O'Brien JT, Erkinjuntti T, Reisberg B, Roman G, Sawada T, Pantoni L, Bowler JV, Ballard C, DeCarli C, Gorelick PB, Rockwood K, Burns A, Gauthier S, DeKosky ST (2003) Vascular cognitive impairment. Lancet Neurology 2, 89-98.

[10] Roman GC, Sachdev P, Royall DR, Bullock RA, Orgogozo JM, Lopez-Pousa S, Arizaga R, Wallin A (2004) Vascular cognitive disorder: a new diagnostic category updating vascular cognitive impairment and vascular dementia. Journal of the Neurological Sciences 226, 81-87.

[11] Liu H, Liu M, Li W, Wu B, Zhang SH, Fang Y, Wang Y (2009) Association of ACE I/D Gene Polymorphism With Vascular Dementia: A Meta-Analysis. Journal of Geriatric Psychiatry and Neurology 22, 10-22.

[12] Liu H, Yang M, Li G-M, Qiu Y, Zheng J, Du X, Wang J-L, Liu R-W (2010) The MTHFR C677T polymorphism contributes to an increased risk for vascular dementia: A meta-analysis. Journal of the Neurological Sciences 294, 74-80.

[13] Liu X, Li L, Liu F, Deng S, Zhu R, Li Q, He Z (2012) ApoE gene polymorphism and vascular dementia in Chinese population: a meta-analysis. Journal of Neural Transmission 119, 387394.

[14] Sun JH, Tan L, Wang HF, Tan MS, Tan L, Li JQ, Xu W, Zhu XC, Jiang T, Yu JT (2015) Genetics of Vascular Dementia: Systematic Review and Meta-Analysis. J Alzheimers Dis 46, 611-629.

[15] Dwyer R, Skrobot OA, Dwyer J, Munafo M, Kehoe PG (2013) Using Alzgene-like approaches to investigate susceptibility genes for vascular cognitive impairment. J Alzheimers Dis 34, 145-154.

[16] Sterne JAC, Gavaghan D, Egger M (2000) Publication and related bias in meta-analysis: Power of statistical tests and prevalence in the literature. Journal of Clinical Epidemiology 53, 1119-1129.

[17] Abdollahi MR, Huang S, Rodriguez S, Guthrie PA, Smith GD, Ebrahim S, Lawlor DA, Day IN, Gaunt TR (2008) Homogeneous assay of rs4343, an ACE I/D proxy, and an analysis in the British Women's Heart and Health Study (BWHHS). Dis Markers 24, 11-17.

[18] Radmanesh F, Devan WJ, Anderson CD, Rosand J, Falcone GJ, Alzheimer's Disease Neuroimaging I (2014) Accuracy of imputation to infer unobserved APOE epsilon alleles in genome-wide genotyping data. Eur J Hum Genet 22, 1239-1242.

[19] Harold D, Abraham R, Hollingworth P, Sims R, Gerrish A, Hamshere ML, Pahwa JS, Moskvina V, Dowzell K, Williams A, Jones N, Thomas C, Stretton A, Morgan AR, Lovestone S, Powell J, 
Proitsi P, Lupton MK, Brayne C, Rubinsztein DC, Gill M, Lawlor B, Lynch A, Morgan K, Brown KS, Passmore PA, Craig D, McGuinness B, Todd S, Holmes C, Mann D, Smith AD, Love S, Kehoe PG, Hardy J, Mead S, Fox N, Rossor M, Collinge J, Maier W, Jessen F, Schurmann B, Heun R, van den Bussche H, Heuser I, Kornhuber J, Wiltfang J, Dichgans M, Frolich L, Hampel H, Hull M, Rujescu D, Goate AM, Kauwe JS, Cruchaga C, Nowotny P, Morris JC, Mayo K, Sleegers K, Bettens K, Engelborghs S, De Deyn PP, Van Broeckhoven C, Livingston G, Bass NJ, Gurling H, McQuillin A, Gwilliam R, Deloukas P, Al-Chalabi A, Shaw CE, Tsolaki M, Singleton $A B$, Guerreiro R, Muhleisen TW, Nothen MM, Moebus S, Jockel KH, Klopp N, Wichmann HE, Carrasquillo MM, Pankratz VS, Younkin SG, Holmans PA, O'Donovan M, Owen MJ, Williams J (2009) Genome-wide association study identifies variants at CLU and PICALM associated with Alzheimer's disease. Nat Genet 41, 1088-1093.

[20] Purcell S, Neale B, Todd-Brown K, Thomas L, Ferreira MA, Bender D, Maller J, Sklar P, de Bakker PI, Daly MJ, Sham PC (2007) PLINK: a tool set for whole-genome association and population-based linkage analyses. Am J Hum Genet 81, 559-575.

[21] Pfrieger FW (2003) Cholesterol homeostasis and function in neurons of the central nervous system. Cellular and Molecular Life Sciences 60, 1158-1171.

[22] Greenberg SM, Briggs ME, Hyman BT, Kokoris GJ, Takis C, Kanter DS, Kase CS, Pessin MS (1996) Apolipoprotein E epsilon 4 is associated with the presence and earlier onset of hemorrhage in cerebral amyloid angiopathy. Stroke 27, 1333-1337.

[23] Chalmers K, Wilcock GK, Love S (2003) APOE epsilon 4 influences the pathological phenotype of Alzheimer's disease by favouring cerebrovascular over parenchymal accumulation of $A$ beta protein. Neuropathology and Applied Neurobiology 29, 231-238.

[24] Stankovic S, Majkic-Singh N (2010) Genetic aspects of ischemic stroke: coagulation, homocysteine, and lipoprotein metabolism as potential risk factors. Critical Reviews in Clinical Laboratory Sciences 47, 72-123.

[25] Anuurad E, Rubin J, Lu G, Pearson TA, Holleran S, Ramakrishnan R, Berglund L (2006) Protective effect of apolipoprotein E2 on coronary artery disease in African Americans is mediated through lipoprotein cholesterol. Journal of Lipid Research 47, 2475-2481.

[26] Beilby J, Rossi E (2000) Broadsheet number 58: Homocysteine and disease. Pathology 32, 262-273.

[27] Hankey GJ, Eikelboom JW (1999) Homocysteine and vascular disease. Lancet 354, 407-413.

[28] Elkins JS, Johnston SC, Ziv E, Kado D, Cauley JA, Yaffe K (2007) Methylenetetrahydrofolate reductase C677T polymorphism and cognitive function in older women. American Journal of Epidemiology 166, 672-678.

[29] Cronin S, Furie KL, Kelly PJ (2005) Dose-related association of MTHFR 677T allele with risk of ischemic stroke: evidence from a cumulative meta-analysis. Stroke 36, 1581-1587.

[30] Pollak RD, Pollak A, Idelson M, Bejarano-Achache I, Doron D, Blumenfeld A (2000) The C677T mutation in the methylenetetrahydrofolate reductase (MTHFR) gene and vascular dementia. Journal of the American Geriatrics Society 48, 664-668.

[31] Bi XH, Zhao HL, Zhang ZX, Zhang JW (2009) Association of RFC1 A80G and MTHFR C677T polymorphisms with Alzheimer's disease. Neurobiology of Aging 30, 1601-1607.

[32] Mansoori N, Tripathi M, Alam R, Luthra K, Ramakrishnan L, Parveen S, Mukhopadhyay AK (2010) IL-6-174 G/C and ApoE Gene Polymorphisms in Alzheimer's and Vascular Dementia Patients Attending the Cognitive Disorder Clinic of the All India Institute of Medical Sciences, New Delhi. Dementia and Geriatric Cognitive Disorders 30, 461-468.

[33] Ward LD, Kellis M (2012) HaploReg: a resource for exploring chromatin states, conservation, and regulatory motif alterations within sets of genetically linked variants. Nucleic Acids Res 40, D930-934.

[34] Westra HJ, Peters MJ, Esko T, Yaghootkar H, Schurmann C, Kettunen J, Christiansen MW, Fairfax BP, Schramm K, Powell JE, Zhernakova A, Zhernakova DV, Veldink JH, Van den Berg LH, Karjalainen J, Withoff S, Uitterlinden AG, Hofman A, Rivadeneira F, t Hoen PA, Reinmaa E, 
Fischer K, Nelis M, Milani L, Melzer D, Ferrucci L, Singleton AB, Hernandez DG, Nalls MA, Homuth G, Nauck M, Radke D, Volker U, Perola M, Salomaa V, Brody J, Suchy-Dicey A, Gharib SA, Enquobahrie DA, Lumley T, Montgomery GW, Makino S, Prokisch H, Herder C, Roden $\mathrm{M}$, Grallert H, Meitinger T, Strauch K, Li Y, Jansen RC, Visscher PM, Knight JC, Psaty BM, Ripatti S, Teumer A, Frayling TM, Metspalu A, van Meurs JB, Franke L (2013) Systematic identification of trans eQTLs as putative drivers of known disease associations. Nat Genet 45, 1238-1243.

[35] Guo X, Chen KH, Guo Y, Liao H, Tang J, Xiao RP (2007) Mitofusin 2 triggers vascular smooth muscle cell apoptosis via mitochondrial death pathway. Circ Res 101, 1113-1122.

[36] Verhoeven K, Claeys KG, Zuchner S, Schroder JM, Weis J, Ceuterick C, Jordanova A, Nelis E, De Vriendt E, Van Hul M, Seeman P, Mazanec R, Saifi GM, Szigeti K, Mancias P, Butler IJ, Kochanski A, Ryniewicz B, De Bleecker J, Van den Bergh P, Verellen C, Van Coster R, Goemans N, Auer-Grumbach M, Robberecht W, Milic Rasic V, Nevo Y, Tournev I, Guergueltcheva V, Roelens F, Vieregge P, Vinci P, Moreno MT, Christen HJ, Shy ME, Lupski $J R$, Vance JM, De Jonghe P, Timmerman V (2006) MFN2 mutation distribution and genotype/phenotype correlation in Charcot-Marie-Tooth type 2. Brain 129, 2093-2102.

[37] Gan X, Wu L, Huang S, Zhong C, Shi H, Li G, Yu H, Howard Swerdlow R, Xi Chen J, Yan SS (2014) Oxidative stress-mediated activation of extracellular signal-regulated kinase contributes to mild cognitive impairment-related mitochondrial dysfunction. Free Radic Biol Med 75, 230-240.

[38] Barsoum MJ, Yuan H, Gerencser AA, Liot G, Kushnareva Y, Graber S, Kovacs I, Lee WD, Waggoner J, Cui J, White AD, Bossy B, Martinou JC, Youle RJ, Lipton SA, Ellisman MH, Perkins GA, Bossy-Wetzel E (2006) Nitric oxide-induced mitochondrial fission is regulated by dynamin-related GTPases in neurons. EMBO J 25, 3900-3911.

[39] Wang X, Su B, Lee HG, Li X, Perry G, Smith MA, Zhu X (2009) Impaired balance of mitochondrial fission and fusion in Alzheimer's disease. J Neurosci 29, 9090-9103.

[40] Gerrish A, Russo G, Richards A, Moskvina V, Ivanov D, Harold D, Sims R, Abraham R, Hollingworth P, Chapman J, Hamshere M, Pahwa JS, Dowzell K, Williams A, Jones N, Thomas C, Stretton A, Morgan AR, Lovestone S, Powell J, Proitsi P, Lupton MK, Brayne C, Rubinsztein DC, Gill M, Lawlor B, Lynch A, Morgan K, Brown KS, Passmore PA, Craig D, McGuinness B, Todd S, Johnston JA, Holmes C, Mann D, Smith AD, Love S, Kehoe PG, Hardy J, Mead S, Fox N, Rossor M, Collinge J, Maier W, Jessen F, Kolsch H, Heun R, Schurmann B, van den Bussche $H$, Heuser I, Kornhuber J, Wiltfang J, Dichgans M, Frolich L, Hampel H, Hull M, Rujescu D, Goate AM, Kauwe JS, Cruchaga C, Nowotny P, Morris JC, Mayo K, Livingston G, Bass NJ, Gurling H, McQuillin A, Gwilliam R, Deloukas P, Davies G, Harris SE, Starr JM, Deary IJ, Al-Chalabi A, Shaw CE, Tsolaki M, Singleton AB, Guerreiro R, Muhleisen TW, Nothen MM, Moebus $S$, Jockel KH, Klopp N, Wichmann HE, Carrasquillo MM, Pankratz VS, Younkin SG, Jones L, Holmans PA, O'Donovan MC, Owen MJ, Williams J (2012) The role of variation at AbetaPP, PSEN1, PSEN2, and MAPT in late onset Alzheimer's disease. J Alzheimers Dis 28, 377-387.

[41] Koyama A, O'Brien J, Weuve J, Blacker D, Metti AL, Yaffe K (2013) The role of peripheral inflammatory markers in dementia and Alzheimer's disease: a meta-analysis. J Gerontol $A$ Biol Sci Med Sci 68, 433-440.

[42] Sharp SI, Aarsland D, Day S, Sonnesyn H, Ballard C (2011) Hypertension is a potential risk factor for vascular dementia: systematic review. International journal of geriatric psychiatry 26, 661-669.

[43] Liu H, Xia P, Liu M, Ji XM, Sun HB, Tao L, Mu QW (2013) PON gene polymorphisms and ischaemic stroke: a systematic review and meta analysis. Int J Stroke 8, 111-123.

[44] Mendonca MI, Dos Reis RP, Freitas AI, Sousa AC, Pereira A, Faria P, Gomes S, Silva B, Santos N, Serrao M, Ornelas I, Freitas S, Freitas C, Araujo JJ, Brehm A, Cardoso AA (2009) Gene-gene interaction affects coronary artery disease risk. Rev Port Cardiol 28, 397-415. 
[45] Sayed-Tabatabaei FA, Oostra BA, Isaacs A, van Duijn CM, Witteman JCM (2006) ACE Polymorphisms. Circ Res 98, 1123-1133.

[46] Schrijvers EMC, Schuermann B, Koudstaal PJ, van den Bussche $H$, Van Duijn CM, Hentschel F, Heun R, Hofman A, Jessen F, Koelsch H, Kornhuber J, Peters O, Rivadeneira F, Ruether E, Uitterlinden AG, Riedel-Heller S, Dichgans M, Wiltfang J, Maier W, Breteler MMB, Ikram MA (2012) Genome-Wide Association Study of Vascular Dementia. Stroke 43, 315-319.

[47] Kim Y, Kong M, Lee C (2013) Association of intronic sequence variant in the gene encoding spleen tyrosine kinase with susceptibility to vascular dementia. World I Biol Psychiatry 14, 220-226.

[48] Lee C, Kim Y (2013) Complex genetic susceptibility to vascular dementia and an evidence for its underlying genetic factors associated with memory and associative learning. Gene 516, 152-157.

[49] Calero M, Gomez-Ramos A, Calero O, Soriano E, Avila J, Medina M (2015) Additional mechanisms conferring genetic susceptibility to Alzheimer's disease. Front Cell Neurosci 9, 138. 


\begin{tabular}{|c|c|c|c|c|c|c|c|}
\hline \multirow[b]{2}{*}{ Polymorphism } & \multicolumn{5}{|c|}{$\begin{array}{l}\text { Cochran-Armitage trend test } \\
\text { with Bonferroni correction }\end{array}$} & \multicolumn{2}{|c|}{$\begin{array}{c}\text { Logistic regression } \\
\text { analysis }\end{array}$} \\
\hline & Cases & Controls & OR (95\% Cl) & $p$ - value & BONF & OR $(95 \% \mathrm{Cl})$ & $p$-value \\
\hline APOE rs429358 allele C & $104 / 724$ & $82 / 910$ & $\begin{array}{c}1.59 \\
(1.17-2.16) \\
\end{array}$ & 0.0026 & 0.018 & $\begin{array}{c}1.66 \\
(1.19-2.32) \\
\end{array}$ & 0.003 \\
\hline APOE rs7412 allele $\mathrm{T}$ & $43 / 779$ & $81 / 905$ & $\begin{array}{c}0.62 \\
(0.42-0.90) \\
\end{array}$ & 0.012 & 0.084 & $\begin{array}{c}0.70 \\
(0.46-1.04) \\
\end{array}$ & 0.078 \\
\hline MTHFR rs1801133 allele T & $363 / 467$ & $1252 / 2186$ & $\begin{array}{c}1.36 \\
(1.16-1.58) \\
\end{array}$ & 0.000095 & 0.0007 & $\begin{array}{c}1.12 \\
(0.93-1.34) \\
\end{array}$ & 0.233 \\
\hline PON-1 rs662 allele $\mathrm{G}$ & $252 / 586$ & $1002 / 2446$ & $\begin{array}{c}1.05 \\
(0.89-1.24) \\
\end{array}$ & 0.563 & 1 & $\begin{array}{c}1.12 \\
(0.92-1.35) \\
\end{array}$ & 0.255 \\
\hline$A C E$ rs 4343 allele $A$ & $339 / 489$ & $396 / 600$ & $\begin{array}{c}1.05 \\
(0.87-1.27) \\
\end{array}$ & 0.618 & 1 & $\begin{array}{c}1.07 \\
(0.87-1.30) \\
\end{array}$ & 0.524 \\
\hline PSEN-1 rs 165932 allele C & $333 / 489$ & $385 / 577$ & $\begin{array}{c}1.02 \\
(0.84-0.12) \\
\end{array}$ & 0.833 & 1 & $\begin{array}{c}1.04 \\
(0.85-1.27) \\
\end{array}$ & 0.706 \\
\hline ACT rs4934 allele $\mathrm{G}$ & $378 / 366$ & $469 / 471$ & $\begin{array}{c}1.04 \\
(0.86-1.26)\end{array}$ & 0.710 & 1 & $\begin{array}{c}1.01 \\
(0.83-1.24)\end{array}$ & 0.917 \\
\hline
\end{tabular}

Table 1: Summary analysis of APOE, MTHFR, PON-1, ACE, PSEN-1 and ACT variants in the European cohort. CochranArmitage trend test: no. of minor alleles in VaD cases; no. minor alleles in controls; Bonferroni corrected p-value (BONF). Logistic regression with age, gender and population origin as covariates odds ratio $(95 \%$ confidence intervals) and resulting $p$-value for each respective analysis as detailed in the first column. 


\begin{tabular}{|l|c|c|}
\hline Alleles & Number of cases & Number of controls \\
\hline Carries any $\varepsilon 2$ allele & 58 & 83 \\
\hline No $\varepsilon 2$ allele & 471 & 864 \\
\hline Carries any $\varepsilon 4$ allele & 138 & 451 \\
\hline No $\varepsilon 4$ allele & 391 & \\
\hline
\end{tabular}

Table 2: APOE epsilon allelic distributions within case and control groups; epsilon allele calls were derived from directly typed genotypes for rs429358 and rs7412 SNPs; APOE $\varepsilon 2$, (OR= 0.67, 95\% Cl 0.46-0.98, p= 0.03 ) and APOE \&4 (OR=1.85, 95\% $\mathrm{Cl} 1.35-2.52, \mathrm{p}=<0.0001)$. 


\begin{tabular}{|c|c|c|c|c|c|}
\hline \multicolumn{6}{|l|}{ Trans-eQTLs } \\
\hline p-value & SNP & Chromosome & Base position & Minor allele & Gene name \\
\hline $2.062 \mathrm{E}-6$ & rs1801133 & 1 & 11778965 & A & PTPRN2 \\
\hline $5.145 \mathrm{E}-6$ & rs1801133 & 1 & 11778965 & A & EXOSC6 \\
\hline $1.393 \mathrm{E}-5$ & rs1801133 & 1 & 11778965 & A & HOXD11 \\
\hline \multicolumn{6}{|l|}{ Cis-eQTLs } \\
\hline $6.085 E-100$ & rs1801133 & 1 & 11778965 & A & MFN2 \\
\hline $6.216 \mathrm{E}-80$ & rs1801133 & 1 & 11778965 & A & PLOD1 \\
\hline $7.818 \mathrm{E}-32$ & rs1801133 & 1 & 11778965 & A & MTHFR, C1orf167 \\
\hline $9.470 \mathrm{E}-13$ & rs1801133 & 1 & 11778965 & A & KIAA2013, CLCN6 \\
\hline 7.157E-9 & rs1801133 & 1 & 11778965 & A & KIAA2013, NPPA \\
\hline 0.002 & rs1801133 & 1 & 11778965 & $A$ & C1orf187 \\
\hline
\end{tabular}

Table 3: Blood eQTL browser (http://genenetwork.nl/bloodeqtlbrowser/) reports multiple trans and cis expression quantitative trait loci for MTHFR rs1801133: protein tyrosine phosphatase, receptor type, N polypeptide 2 (PTPRN2); exosome component 6 (EXOSC6); homeobox D11 (HOXD11); Mitofusin 2 (MFN2); procollagen-lysine, 2-oxoglutarate 5-dioxygenase 1 (PLOD1); methylenetetrahydrofolate reductase (MTHFR), chromosome 1 open reading frame 167; KIAA2013; chloride channel, voltage-sensitive 6 (CLCN6); natriuretic peptide A (NPPA); dorsal inhibitory axon guidance protein (DRAXIN). 